\title{
41. BATHYMETRIC AND TECTONIC EVOLUTION OF THE SOUTHERN MEXICO ACTIVE MARGIN, DEEP SEA DRILLING PROJECT LEG 66 ${ }^{1}$
}

\author{
Kenneth J. McMillen, Gulf Research \& Development Company, Pittsburgh, Pennsylvania \\ and \\ Steven B. Bachman, Department of Geology, University of California, Davis, California ${ }^{2}$
}

\section{INTRODUCTION}

The development of active margins through time occurs either by the accretion of sediments and ocean crust derived from the subducted plate onto the upper plate (e.g., Seely et al., 1974) or by "subduction erosion" of the upper plate by the lower so that crust and sediments are planed off and carried to depths by the downgoing slab. The accretionary zone is now thought to be formed mainly of underthrust and uplifted trench sediments rather than offscraped oceanic sediments (Karig and Sharmon, 1975; Moore and Karig, 1976). The currently accepted accretionary zone models of Seely et al. (1974) and Karig and Sharmon (1975) assume that successive emplacement of trench turbidites at the toe of a slope causes slabs emplaced earlier to be uplifted and rotated landward. Uplift rates should decrease toward the shelf/ slope break in a regular fashion. Small basins are isolated by blockage of lower slope sediment routes by the emplaced accretionary zone sediments, and they grow as the zone is uplifted. The accretionary zone model is based on seismic reflection data and has been supported by facies and microfaunal analysis of sediments exposed on Nias Island in the Sumatra active margin (Moore and Karig, in press), where trench and lower slope sediments have been uplifted to the shelf edge. Progressive accretion had not been documented by deep sea drilling or other sampling until Leg 66.

Sediments of the southern Mexico active margin (Fig. 2) presented an excellent opportunity to test the accretionary zone models because the accretionary zone with landward-dipping reflectors could be distinguished from the slope apron on seismic reflection profiles (Shipley, this volume), and the coarse, sandy trench sediments are lithologically so distinct from slope sediments that older, uplifted trench deposits were easily recognized. This recognition of older trench sediments is important for two reasons: (1) It allowed us reasonably to infer that we had penetrated the accretionary zone, and (2) by assuming a reasonable depth of deposition for trench sediments it gave us a paleobathymetric control point for determining rates of vertical tectonic movement.

\footnotetext{
${ }_{2}^{1}$ Initial Reports of the Deep Sea Drilling Project, Volume 66. York.
}

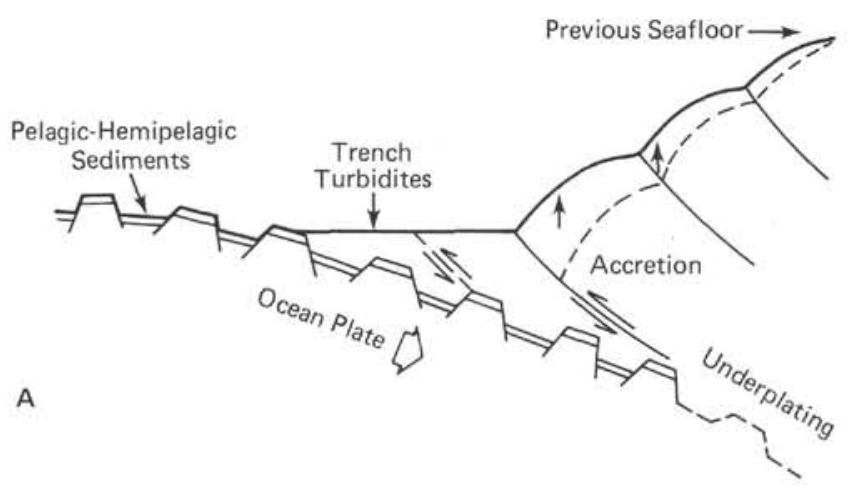

B

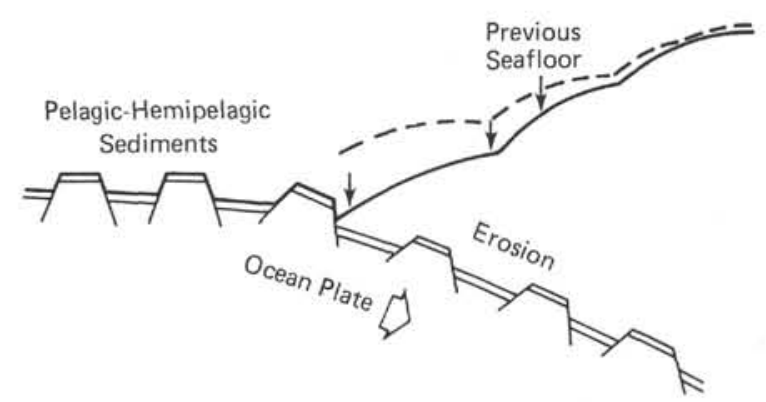

Figure 1. Model of bathymetric response of accretion (A) and subduction erosion (B) at active margins.

In this chapter we first describe our techniques for estimating bathymetry of sediments at the time of deposition. After constructing bathymetric curves for each site, we derive rates of vertical uplift by subtracting the effect of sediment accumulation from the bathymetric curves. Finally, we discuss the implications of our vertical tectonic rates as regards the accretionary zone model.

\section{BATHYMETRIC ESTIMATES}

Estimating the depths of deposition of sediments can be an invaluable tool in understanding the tectonic history of a basin or margin. Subtracting sediment thicknesses from a bathymetric curve produces a record of the vertical tectonics which can be very different from the bathymetric history. Bathymetric estimates are best if based on faunal evidence, since facies and lithologic evidence are usually regarded as less reliable. Because benthic faunas are not well preserved in Leg 66 sediments, we were obliged to turn to these less reliable indi- 


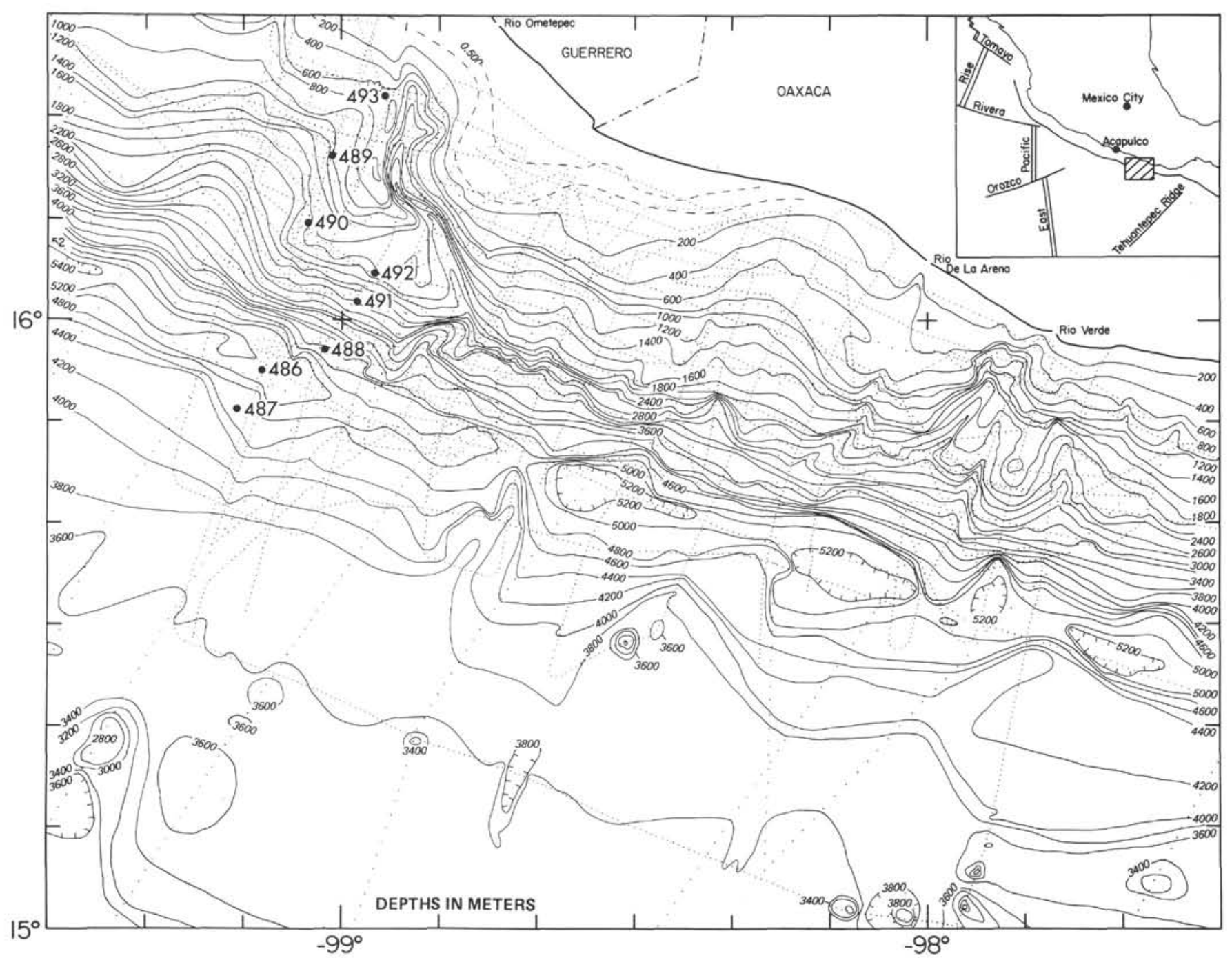

Figure 2. Bathymetry of the Leg 66 area and location of drill sites (after Shipley et al., 1980). (+ = below the inferred CCD level.)

cators. Constraints which we place on facies and lithologic evidence based on studies of the modern southern Mexico margin, and the similarity of results derived from independent criteria, strengthen our interpretations.

To derive bathymetric curves, we have used the following types of data: (1) benthic foraminiferal faunas, (2) carbonate preservation in the cores, (3) the presence of a sandy facies similar to modern trench facies at the base of lower trench slope accretionary zone sites, (4) the presence of strandline facies at the base of upper slope sites on continental basement, and (5) trace fossil assemblages.

\section{Benthic Foraminiferal Faunas}

Owing to intense carbonate dissolution, benthic foraminifers are generally poorly preserved in Leg 66 sediments, except in the upper few cores of each site. Only in upper slope Sites 489 and 493 is preservation adequate for foraminiferal faunas to be useful. Both Sites 489 and 493 (see site chapters, Fig. 2) contain lower Miocene faunas near the base of the holes, which we in- terpret to indicate a marine transgression to bathyal depths before carbonate dissolution obliterates the faunal record. The upper portion of Site 493 contains an upper Miocene through Quaternary record of bathyal assemblages, suggesting sediment deposition near present-day water depths.

\section{Carbonate Preservation}

The upper portion of all Leg 66 sites contains wellpreserved calcareous foraminifers and nannofossils. This carbonate is dissolved at varying depths in the holes. Dissolution may be a function of the early depth of deposition; because the CCD is relatively shallow in the East Pacific (Berger, 1977), older sediments at the lower slope sites may have been deposited beneath it and, as the sites were uplifted, been surmounted by younger sediments deposited above the CCD. This appears to be the case at Sites 489 and 493 , where we have benthic foraminiferal control in the paleobathymetry. If it is true at the other sites, and if we can estimate past levels of the Eastern Pacific CCD, we can use the carbonate preservation level in the cores as a depth in- 
dicator. To document this kind of an argument we need to know (1) the present CCD in the southern Mexico margin, (2) the Late Cenozoic history of the CCD in this region, and (3) the levels of carbonate preservation at the Leg 66 sites.

To document the level of the modern CCD, we examined sediment smear slides from the top and base of piston cores collected during site surveys offshore southern Mexico (see McMillen and Haines, this volume) and from the top of the uppermost core from the Leg 66 sites. The results, plotted on Figure 3, show the following:

1) The total number of planktonic foraminifers per slide as well as the abundance of foraminifers compared

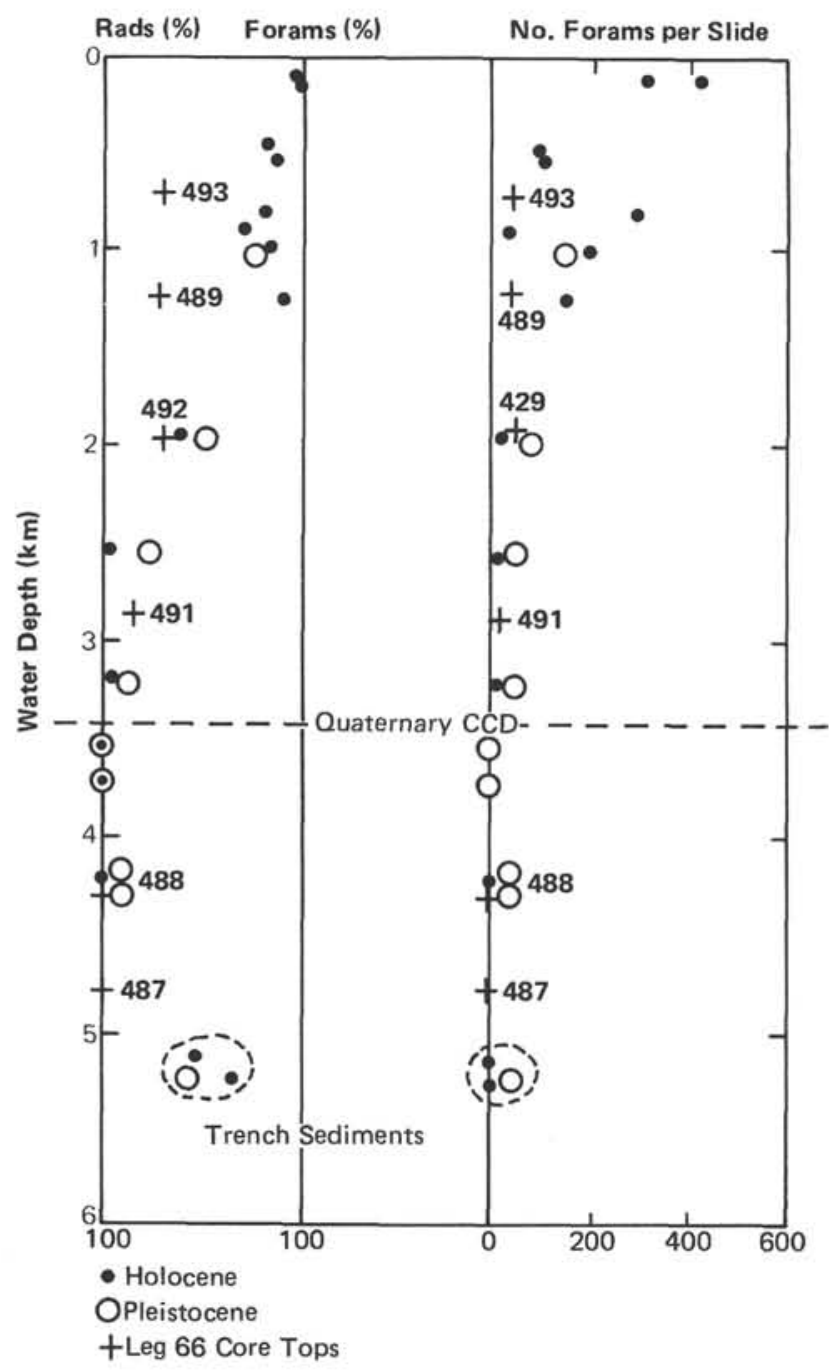

Figure 3. Preservation of planktonic foraminifers in southern Mexico margin sediments. Left-hand side of diagram shows ratio of foraminifers to radiolarians; right-hand side diagram shows total number of foraminifers per slide. Data was compiled from counts of smear slides from tops (solid dots) and bases (open circles) of site survey piston cores and from uppermost sediments of Leg 66 holes (crosses). The Quaternary CCD is $3.4 \mathrm{~km} \pm 0.2 \mathrm{~km}$. Dashed circles around trench sediments indicate reworked faunas from shallower water, also present in Pleistocene samples from inner and outer lower trench slope. to radiolarians decrease with increasing water depth until the calcareous microfossils are absent in lower slope cores between 3.5 and $4 \mathrm{~km}$. This indicates a Quaternary CCD near $3.4 \mathrm{~km} \pm 0.2 \mathrm{~km}$.

2) Holocene midslope sediments contain fewer preserved planktonic foraminifers than do Pleistocene sediments, consistent with similar observations offshore Oregon (Duncan et al., 1970) and Guatemala (McMillen, 1979).

3) Inner and outer lower trench slope Pleistocene sediments and Quaternary trench sediments contain redeposited foraminifers transported by downslope processes, and possibly by geostrophic currents from shallower water, and buried rapidly before dissolution can take effect. Similarly, the shallow-water benthic foraminiferal fauna of the upper portion of Site 487 (ocean plate, see site chapter) was evidently deposited in this way.

The Late Cenozoic history of the CCD in the East Pacific must be inferred from other studies. Berger (1973) and especially van Andel et al. (1975) suggest that the CCD has remained roughly the same since the Eocene. Van Andel et al. (1975), however, have documented minor oceanographic changes in the equatorial and central North Pacific which indicate that the late Miocene CCD was roughly 0.25 to $0.5 \mathrm{~km}$ shallower than at present and that the early Miocene CCD may have been roughly $0.2 \mathrm{~km}$ shallower in the North Pacific and at roughly its present depth near the equator. We have used the North Pacific curve of van Andel et al. (1975) to estimate the Late Cenozoic behavior of the CCD near the southern Mexico margin but have adjusted the curve so that the present CCD coincides with our estimates for the modern CCD based on our piston core studies (Fig. 4). Thus some of the effects of proximity to the margin may be corrected, but there may still be an error caused by ocean currents changing through time. This modified curve is used to estimate the bathymetry of Leg 66 sediments. We note the level and

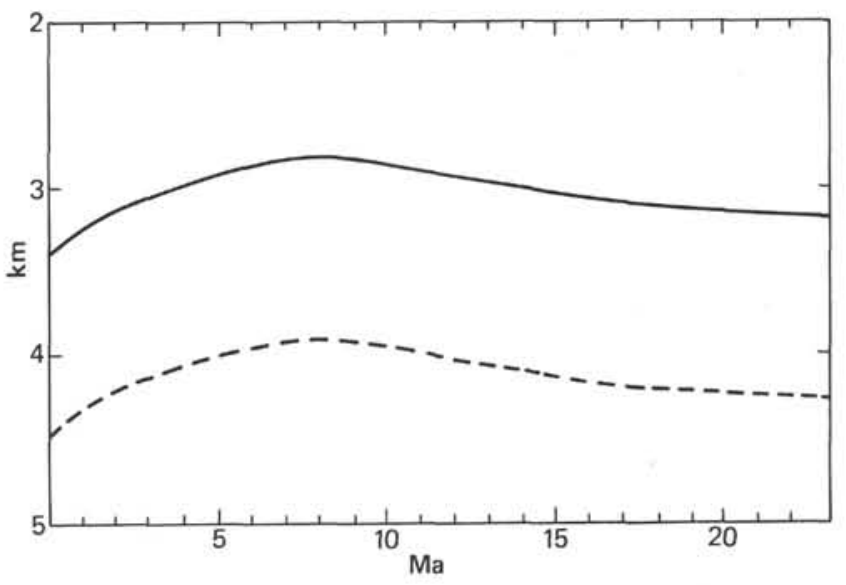

Figure 4. Lower curve, dashed: Cenozoic history of the CCD in the North Central Pacific (from van Andel et al., 1975). Upper curve, solid: Inferred Cenozoic history of the CCD on the southern Mexico margin. This curve is the same as the one below, adjusted upward to the present $C C D$. 
age of sediments in the sites where planktonic foraminifers disappear and derive the water depth from the estimated level of the CCD at that particular time. It is important to note that the maximum amount of vertical change through time of the CCD documented by van Andel et al. (1975) is $0.5 \mathrm{~km}$ (Fig. 4). Even though our estimates of vertical change in the CCD for the margin may be in error, the magnitude of error is probably still small when compared with our estimates of uplift, which amount to several kilometers for most sites.

We next documented the carbonate preservation in Leg 66 cores by counting the same foraminiferal/ radiolarian ratios to compare with the near-surface sediment survey. The results (Fig. 5) show that lower slope
Sites 491,492 , and 490 as well as upper slope Sites 489 and 493 contain well-preserved carbonate in the upper levels of the holes. In addition, Sites 489 and 493 contain carbonate at the base of the section near continental basement. The carbonate preservation in upper Miocene through Quaternary sediments appears to be cyclic, and many episodes of good and poor preservation are roughly correlative, suggesting short-term variations in the CCD similar to the late Quaternary examples. The lowest levels of significant carbonate preservation at Sites 490, 491, 492, and 493 are at different stratigraphic levels-younger in downslope cores-and at different core depths-shallower in downslope cores. These observations strongly suggest but do not prove that dia-

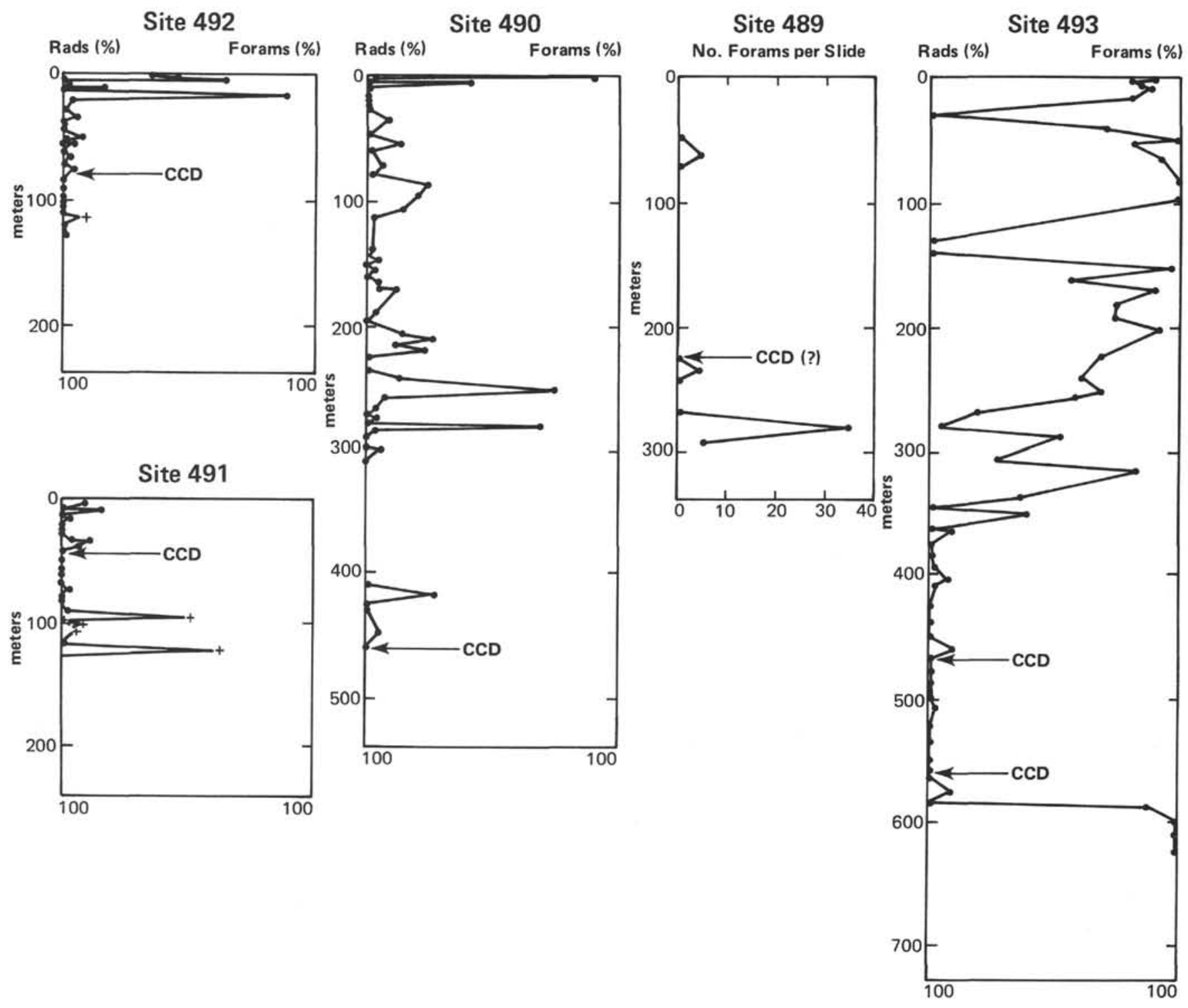

Figure 5. Ratios of foraminifers to radiolarians at Leg 66 sites. These data are directly comparable with data used to establish the modern CCD in Figure 3. Sites 491 and 492 have sporadic occurrences of planktonic foraminifers below the inferred CCD level, as shown by + symbols (depth of termination of abundant foraminifers in the cores). Even though the ratio of foraminifers to radiolarians is high in these sporadic occurrences, they are based on very few individuals, usually less than 10 . Because sedimentation rates are higher in these portions of the sites, the calcareous microfossils are regarded as reworked, in the same manner that rare occurrences of planktonic foraminifers in Quaternary trench and lower trench slope sediments represent reworked faunas. 
genetic dissolution does not have a significant effect on carbonate preservation. Studies of East Pacific piston cores have shown that diagenetic carbonate dissolution takes place in the-upper few tens of centimeters below the seafloor, where the dissolution is affected by sediment mixing to that depth (Broecker and Broecker, 1974). The carbonate record at a meter or more of core depth should have passed through the level of significant in situ dissolution and any remaining carbonate be preserved indefinitely. Since dissolution occurs in unconsolidated muds, tectonic dewatering of the sediment has not yet occurred and fluid migration is probably not a factor in dissolution. Thus we believe that the disappearance of carbonate in a core is correlative with submergence of the depositional site below the CCD.

\section{Facies}

In the lowermost portion of all sites drilled in the inferred accretionary zone of the southern Mexico margin, we recovered medium- to coarse-grained, clean, uncemented sands similar to those recovered in the modern trench by piston cores and at Site 486 . Because we did not recover similar sandy sediments in any of the site survey piston cores from the inner and outer trench slope (McMillen and Haines, this volume), we interpret the buried sands at Sites 488,491 , and 492 to be uplifted trench deposits. The depth of deposition of these sandy sediments must be inferred from modern trench depths. For Site 492, the late Miocene trench depth is inferred to have been greater than the present $5-\mathrm{km}$ depth because relatively older and therefore cooler ocean crust was being subducted at that time (Menard, 1978). We have therefore used a late Miocene trench depth of $6 \mathrm{~km}$ in our calculations. Upper slope Sites 489 and 493 contain sandy sediments near the base of the holes, but in this case the presence of a shallow-water molluscan fauna indicates strandline deposition.

\section{Trace Fossil Assemblages}

A deep-water trace fossil assemblage composed of Planolites, Chondrites, Zoophycos, and Teichichnus (see McMillen and Lundberg, this volume) occurs in the lower portion of Sites 491 and 492 (Fig. 4). This assemblage has been inferred to indicate roughly $4 \mathrm{~km}$ or greater water depths in Cenozoic deep sea sediments (Kennedy, 1975; Ekdale, 1978). A similar assemblage lacking Teichichnus occurs in the lower portions of Sites 489 and 493 and is interpreted to represent slightly shallower depths, perhaps near $3 \mathrm{~km}$ (Fig. 4). The presence of these deep-water trace fossil assemblages is consistent with the inferred depth of deposition based on the facies and carbonate preservation evidence.

\section{Bathymetric Curves}

The bathymetric evidence from Leg 66 sites is tabulated in Table 1 and illustrated in Figure 6. The curves are drawn on the basis of present sea levels of the sites, ages and depths of the CCD interception levels, and depths of inferred trench and strandline facies. Trace fossil and foraminiferal assemblages support these
Table 1. Bathymetric estimates for Leg 66 sediments, based on facies (F) and calcite compensation depth (CCD).

\begin{tabular}{|c|c|c|c|}
\hline \multicolumn{2}{|l|}{ Site 488} & \multicolumn{2}{|l|}{ Site 491} \\
\hline $\begin{array}{l}\text { Present depth } \\
\text { Depth } \sim 1 \mathrm{Ma}\end{array}$ & $\begin{array}{l}4254 \\
\sim 5000(\mathrm{~F})\end{array}$ & $\begin{array}{l}\text { Present depth } \\
\text { Depth } \\
\quad 2 \mathrm{Ma} \\
3.7 \mathrm{Ma}\end{array}$ & $\begin{array}{l}2883 \\
3200(\mathrm{CCD}) \\
\sim 5000(\mathrm{~F})\end{array}$ \\
\hline Site 492 & & Site 490 & \\
\hline $\begin{array}{l}\text { Present depth } \\
\text { Depth } \\
\quad 5.4 \mathrm{Ma} \\
10 \mathrm{Ma}\end{array}$ & $\begin{array}{l}1935 \\
3000(\mathrm{CCD}) \\
\sim 6000(\mathrm{~F})\end{array}$ & $\begin{array}{l}\text { Present depth } \\
\text { Depth } 4 \mathrm{Ma}\end{array}$ & $\begin{array}{l}1761 \\
3000(\mathrm{CCD})\end{array}$ \\
\hline Site 489 & & Site 493 & \\
\hline $\begin{array}{l}\text { Present depth } \\
\text { Depth } \\
\quad 21 \mathrm{Ma} \\
\sim 22.5 \mathrm{Ma}\end{array}$ & $\begin{array}{l}3200(\mathrm{CCD}) \\
0(\mathrm{~F})\end{array}$ & $\begin{array}{l}\text { Present depth } \\
\text { Depth } \\
\qquad \begin{array}{l}16-18 \mathrm{Ma} \\
\sim 21.5 \mathrm{Ma}\end{array}\end{array}$ & $\begin{array}{l}645 \\
>3200(\mathrm{CCD}) \\
0(\mathrm{~F})\end{array}$ \\
\hline
\end{tabular}

Note: Depths are in meters.

curves. All lower and middle slope Sites, 488, 491, 492, and 490 show evidence of shallowing in younger sediments. Upper slope Sites 489 and 493 have more complicated bathymetric histories. Both begin with early Miocene strandline deposition on eroded continental basement. Water depths deepened rapidly to roughly 3 $\mathrm{km}$ in the early Miocene, below the level of the CCD. At Site 489 the record between lower Miocene and Quaternary is missing, but at upslope Site 493 carbonate preservation indicates that the seafloor shallowed above the CCD again in the early Miocene. Increasing carbonate content in the sediments suggests that gradual shallowing continued to the present depth of 645 meters.

\section{VERTICAL TECTONICS}

We derived rates of vertical tectonic movement for Leg 66 sites by subtracting the total sediment accumulation from the bathymetric control points for each site. Taking the base of a site as a starting point, the amount of sediment that had accumulated at each successively higher control point was subtracted from the water depth at that time to establish a tectonic position for the site. Rates of vertical tectonics were then computed by dividing the difference in vertical tectonic position at successive times by the time interval. The rates are tabulated in Table 2 and shown graphically in Figure 4 as slopes on the uplift curves. Eustatic changes in sea level were not taken into account because (1) we have so few data points and (2) the magnitude of these bathymetric changes makes eustatic effects insignificant.

The results of vertical tectonic calculations can be summarized for three zones: the accretionary zone in lower and middle slope Sites 488, 491, and 492; the transition zone of Site 490; and the continental edge in upper slope Sites 489 and 493 .

The accretionary zone includes sediments near the base of the cores that were presumably deposited in the trench and subsequently detached from the downgoing plate and included in the accretionary zone. Rates of 


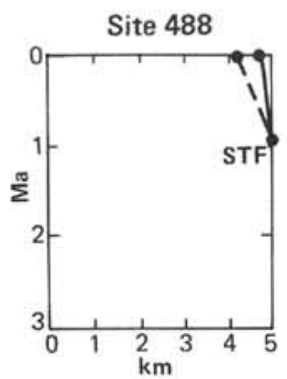

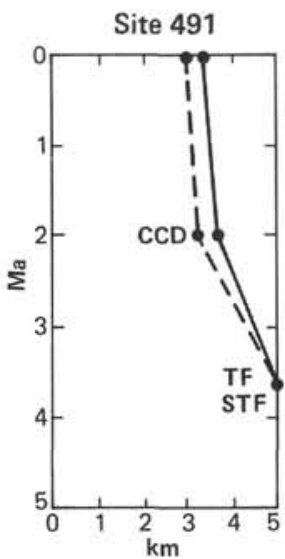

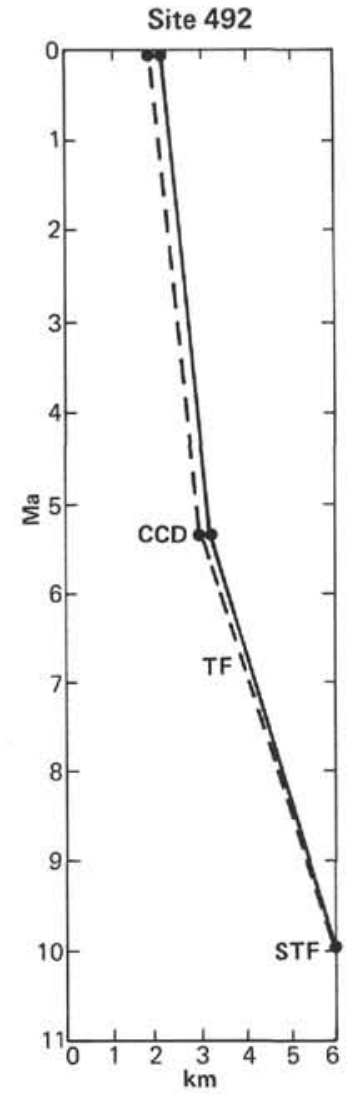

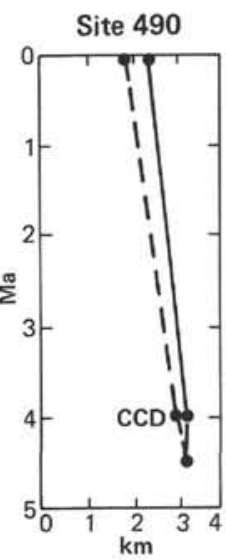
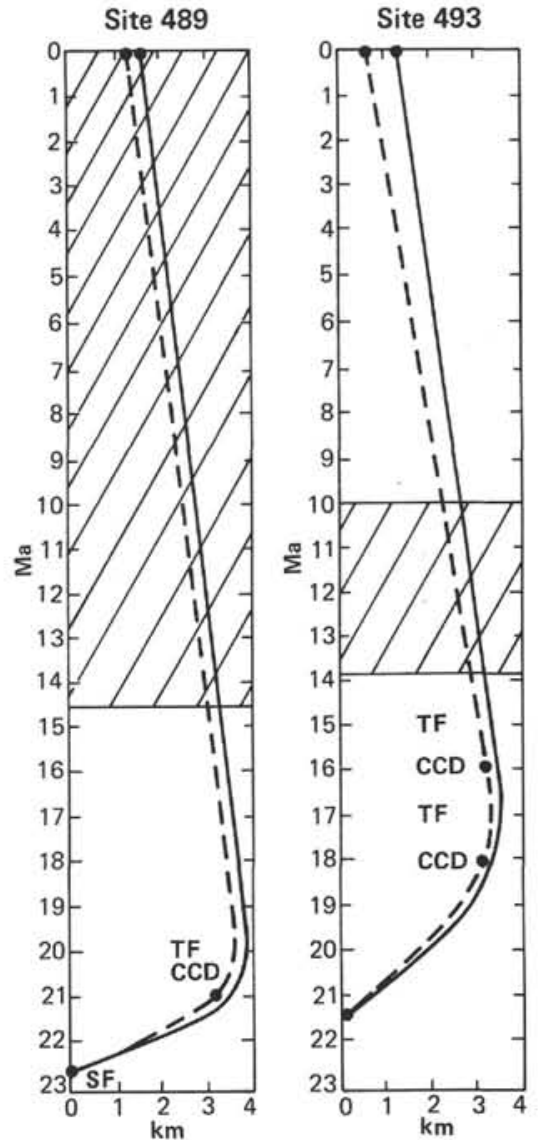

Figure 6. Bathymetry (dashed lines) and vertical tectonics (solid lines) of Leg 66 sites. Control points for bathymetry are the present water depth; the presence of a sandy trench facies (STF) in Sites 488, 491, and 492; the presence of sandy strandline facies in Sites 489 and 493 (SF); and the inferred level of the calcite compensation depth (CCD). The location of deep-water trace fossil assemblages (TF) is also shown. Cross-hatched areas represent hiatuses where the curves are inferred. Vertical tectonic rates are tabulated in Table 2.

uplift of these sediments immediately after deposition are uniformly high (400-800 m/m.y.; Fig. 6; Table 2). These high rates of uplift decrease with time, as seen from the paleobathymetric evidence in overlying slope sediments; during the time of deposition of the relatively undeformed overlying slope sediments, uplift rates are 135 to $180 \mathrm{~m} / \mathrm{m}$.y. Thus uplift rates vary considerably with the tectonic site of the sediments.

The transition zone borehole includes sediments that were apparently all deposited on the slope. Uplift rates $(\sim 200 \mathrm{~m} / \mathrm{m} . \mathrm{y}$.) are only slightly higher than those for more seaward slope positions. The rapid uplift rates seen at the base of the seaward slope cores were not encountered at Site 490; this is consistent with the suggestion (see site chapter) that we did not penetrate accreted trench deposits at this site.

Drilling the two continental edge sites recovered sediments that document rapid subsidence (up to 940 $\mathrm{m} / \mathrm{m} . \mathrm{y}$.) in the early Miocene, followed by more gradual uplift. The uplift and subsidence rates for the two sites are approximately the same, but the sites were at their deepest at different times. For the seaward site (489) subsidence ended and uplift began about $20 \mathrm{Ma}$; at the landward site (493) uplift did not begun until about 17 Ma.

\section{DISCUSSION}

Leg 66 drilling off Oaxaca confirms that sediment accretion has occurred along part of the Middle America Trench during at least the past $10 \mathrm{~m} . \mathrm{y}$. The difference in uplift rates associated with various settings in the subduction complex suggests the importance of at least two tectonic processes during subduction and accretion. At the toe of the inner trench slope, trench deposits are uplifted rapidly soon after deposition; at Site 488 , 1 -m.y.-old trench deposits are uplifted 400 meters, whereas the inferred trench deposits at the base of the cores at Sites 491 and 492 were uplifted 600 to 800 $\mathrm{m} / \mathrm{m} . \mathrm{y}$. during the first several million years after deposition. In contrast, the lower slope deposits landward of the toe of the slope are uplifted at much slower rates $(135$ to $180 \mathrm{~m} / \mathrm{m} . \mathrm{y}$.). The change from rapid to slower modern slope uplift rates occurs between Sites 488 and 491 , within approximately $10 \mathrm{~km}$ of the trench. This change in uplift rates with position on the slope can also be traced through time as the accretionary zone enlarged seaward. Both Sites 491 and 492 show a decrease in uplift rates upward in the drilled section (Fig. 6; Table 2) contemporaneous with a transition from trench deposition to slope deposition. Thus trench deposits 
Table 2. Vertical tectonic rates at Leg 66 sites.

\begin{tabular}{|c|c|c|}
\hline Site & Rate & Position \\
\hline \multicolumn{3}{|l|}{488} \\
\hline$\sim 1$ Ma-present & 400 (uplift) & $\begin{array}{l}\text { Lower and middle } \\
\text { trench slope }\end{array}$ \\
\hline \multicolumn{3}{|l|}{491} \\
\hline $\begin{array}{l}3.7-2 \mathrm{Ma} \\
2 \mathrm{Ma} \text {-present }\end{array}$ & $\begin{array}{l}800 \text { (uplift) } \\
135 \text { (uplift) }\end{array}$ & \\
\hline \multicolumn{3}{|l|}{492} \\
\hline $\begin{array}{l}\text { 10-5.4 Ma } \\
5.4 \mathrm{Ma} \text {-present }\end{array}$ & $\begin{array}{l}610 \text { (uplift) } \\
180 \text { (uplift) }\end{array}$ & \\
\hline \multicolumn{3}{|l|}{490} \\
\hline \multicolumn{2}{|l|}{489} & Transition zone \\
\hline $\begin{array}{l}22.5-21 \mathrm{Ma} \\
\text { early Miocene-present }\end{array}$ & $\begin{array}{l}\sim 910 \text { (subsidence) } \\
\sim 130 \text { (uplift) }\end{array}$ & Continental edge \\
\hline \multicolumn{3}{|l|}{493} \\
\hline $\begin{array}{l}21.5-18 \mathrm{Ma} \\
16 \mathrm{Ma} \text {-present }\end{array}$ & $\begin{array}{l}\sim 940 \text { (subsidence) } \\
125 \text { (uplift) }\end{array}$ & \\
\hline
\end{tabular}

Note: Uplift and subsidence rates are in $\mathrm{m} / \mathrm{m} . \mathrm{y}$. Note the rapid initial uplift of lower trench slope sites, which ranges between 400 and $800 \mathrm{~m} / \mathrm{m} . y$. , and subsequent slower uplift of 135 and 180 $\mathrm{m} / \mathrm{m}$.y. We interpret the higher earlier rate as due to emplacement of underthrust stacks of trench fill into the accretionary zone and the slower rates as due to regional uplift produced by underplating by subducted material. Sites 489 and 493 show early stages of rapid downward movement occurring either in early stages of subduction or during a phase of strike-slip motion and continental truncation, followed by a phase of slower regional uplift at roughly $130 \mathrm{~m} / \mathrm{m} . \mathrm{y} .$, similar to regional rates of the lower trench slope sites.

were accreted, uplifted rapidly at the toe of the slope, and then uplifted more slowly as the locus of trench deposition moved seaward and the accreted trench deposits were covered by slope deposits. Once the high rate of uplift decreases landward of the toe of the slope, it reaches a more or less constant rate up the slope and through the transition zone to the continental crust.

The continental edge uplift rates are more complex than those for the accretionary zone. Uplift rates during the last $16 \mathrm{~m} . \mathrm{y}$. or so approximate slower rates of the trench slope. However, the early Miocene subsidence rates from Sites 489 and 493 (Table 2) are very highapproaching $1 \mathrm{~km} / \mathrm{m} . \mathrm{y}$. This early subsidence is unrelated to the uplift trends of the last 16 m.y. and may be part of an earlier tectonic regime along the margin. It suggests that the onset of the modern phase of margin accretion was in the early Miocene age or later.

The geometry of accretion along the Oaxaca margin is constrained by two factors: (1) Although uplift rates are high at the toe of the slope and decrease quickly in a landward direction, they become more or less constant within $10 \mathrm{~km}$ of the trench and remain so through the transition zone and over the edge of the continent; and (2) . sedimentary sequences, represented by landwarddipping reflectors on seismic reflection profiles across the margin, are initially tilted landward at the toe of the slope and remain tilted at the same angle through the remainder the accretionary zone. Thus the continued uplift of the slope and continental edge cannot be explained by progressive landward tilting of imbricate thrust packets. The sediments are not progressively tilted in a more landward position; nor do the uplift rates progressively decrease in a landward direction, as predicted by rotation of imbricate packets.

A more plausible explanation for the constant uplift rates of the entire margin is that material on the ocean plate is thrust under the toe of the trench slope and then later underplated farther beneath the accretionary zone and edge of the continent. Thus accretion occurs in two ways: (1) Material is scraped off the downgoing plate at the toe of the slope, remains there, and is progressively uplifted; and (2) other material remains attached to the ocean plate, is thrust under the toe of the slope, and is underplated onto the margin at greater depths. In addition, younging of the subducted plate with time may contribute roughly $100 \mathrm{~m} / \mathrm{m}$.y. uplift. The remaining crust and sediments are carried down the subduction zone. Relative percentages of material offscraped, underplated, and subducted are calculated elsewhere (Watkins et al., this volume).

\section{CONCLUSIONS}

We can make the following conclusions regarding the bathymetric and tectonic history of the southern Mexico active continental margin:

1) Bathymetric estimates of trench slope sites based on lithostratigraphic evidence only-i.e., presence of trench facies and carbonate content of slope sediments-results in a coherent bathymetric pattern that is similar for each site. Trace fossil assemblage data support these depth estimates.

2) Vertical tectonic history of the accretionary zone shows rapid uplift of roughly 400 to $800 \mathrm{~m} / \mathrm{m}$.y. as trench sediments are emplaced into the inner wall. Uplift rates then slow to roughly 135 to $180 \mathrm{~m} / \mathrm{m}$.y. as sedimentary underplating of the entire margin continues.

3) Vertical tectonic history of the seaward lip of continental basement shows a more complex pattern since the beginning of the early Miocene. Rapid transgression and subsidence of the margin in the early Miocene was followed by slow uplift at rates similar to regional uplift rates of the entire accretionary zone. This regional uplift probably reflects the present subduction episode. Although the record is obscure, uplift appears to have been initiated in the early Miocene immediately after the rapid initial subsidence phase. If this shift in vertical tectonics of the continental lip marks the beginning of the present subduction phase, it suggests that it began roughly $17 \mathrm{Ma}$, considerably earlier than the uplift of the oldest trench sediments recovered at Site 492 (11 Ma).

\section{ACKNOWLEDGMENTS}

We would like to thank Christopher Kendall and Jeffrey May for reviewing the manuscript. 


\section{REFERENCES}

Berger, W. H., 1973. Cenozoic sedimentation in the eastern tropical Pacific. Geol. Soc. Am. Bull., 84:1941-1954.

, 1977. Carbon dioxide excursions and the deep-sea record: Aspects of the problem. In Anderson, N. R., and Malahoff, A. (Eds.), The Fate of Fossil Fuel $\mathrm{CO}_{2}$ in the Oceans: New York (Plenum Press), pp. 505-542.

Broecker, W. S., and Broecker, S., 174. Carbonate dissolution on the western flank of the East Pacific Rise. In Hay, W. W. (Ed.), Studies in Paleo-Oceanography: Tulsa (Society of Economics Paleontologists and Limeralogists, Special Publication No. 20), pp. 44-57.

Duncan, J. R., Flower, G. A., and Kulm, L. D., 1970. Planktonic foraminiferan-radiolarian ratios and Holocene-late Pleistocene deep-sea stratigraphy off Oregon. Geol. Soc. Am. Bull., 81: 561-566.

Ekdale, A. A., 1978. Trace fossils in Leg 42A cores. In Hsü, K., Montadert, L., et al., Init. Repts. DSDP, 42, Pt. 1: Washington (U.S. Govt. Printing Office), 821-827.

Karig, D. E., 1974. Tectonic erosion of trenches. Earth Planet. Sci. Lett., 21:209-212.
Karig, D. E., and Sharmon, G. F., III, 1975. Subduction and accretion in trenches. Geol. Soc. Am. Bull., 86:377-389.

Kennedy, W. J., 1975. Trace fossils in carbonate rocks. In Frey, R. W. (Ed.), The Study of Trace Fossils: New York (SpringerVerlag), pp. 377-398.

McMillen, K. J., 1979. Radiolarian ratios and the Pleistocene-Holocene boundary. Trans. Gulf Coast Assoc. Geol. Soc., 29:298-301.

Menard, H. W., 1978. Fragmentation of the Farallon plate by pivoting subduction. J. Geol., 86:99-110.

Moore, G. F., and Karig, D. E., 1976. Development of sedimentary basins on the lower trench slope. Geology, 4:501-504. in press. Structural geology of Nias Island, Indonesia: Implications for subduction zone tectonics. Am. J. Sci.

Seely, D. R., Vail, P. R., and Walton, G. G., 1974. Trench slope model. In Burk, C. A., and Drake, C. L. (Eds.), The Geology of Continental Margins: New York (Springer-Verlag), pp. 249-260.

Shipley, T. H., McMillen, K. J., Watkins, J. S., et al., 1980. Continental margin and lower slope structures of the Middle America Trench near Acapulco (Mexico). Mar. Geol., 35:65-82.

van Andel, Tj. H., Heath, G. R., and Moore, T. C., Jr., 1975. Cenozoic history and paleo-oceanography of the central equatorial Pacific Ocean. Geol. Soc. Am. Mem., Vol. 143. 